Brit. J. industr. Med., 1963, 20, 169.

\title{
THE SUCCESSFUL PREVENTION OF LEAD POISONING IN THE GLAZING OF EARTHENWARE IN THE NORTH STAFFORDSHIRE POTTERIES*
}

\author{
BY \\ A. MEIKLEJOHN \\ From the Department of Industrial Health, University of Glasgow
}

(RECEIVED FOR PUBLICATION FEBRUARY 15,1963 )

\begin{abstract}
In 1572 an extensive epidemic of disease characterized by severe abdominal colic, later identified as lead poisoning, occurred in France in the province of Poitou. Citois named the disease colica Pictonum, that is the colic of the Pictones, the ancient Celtic tribe who inhabited the area. Thereafter the term was used generically for lead poisoning, otherwise plumbism or saturnism. The origin of the poisoning was traced to the practice of vintners who sophisticated sour acid wines with lead oxide. This adulteration restored the sweetness of the wine by the formation of sugar of lead, lead acetate. Similar outbreaks of poisoning were traced to the same fraudulent practice in the winegrowing districts of Germany and Spain. The preparation and storage of food and drink in containers of pewter and lead glazed earthenware resulted in accidental contamination of the substances, the consumption of which caused acute and chronic plumbism. Among the most frequently lead-contaminated liquors was Devonshire cyder, hence Devonshire colic. Occupational lead poisoning was described among lead miners and smelters in the mid-sixteenth century. Thereafter the disease was observed in a wide variety of trades and processes. The subject was comprehensively reviewed by Tanquerel des Planches in 1839.

Among the workmen frequently affected were dippers in the pottery industry where lead oxide and lead carbonate were constituents of the glaze. The disease appeared as a serious problem among dippers and their assistants in North Staffordshire, the centre of the manufacture of earthenware and china in Great Britain. The manifestations of the disease included colic, convulsions, paralysis of limbs, blindness, and general emaciation. Female lead workers suffered excessively from abortions and miscarriages and many of their infants died of fits. The situation became so serious that the Government were compelled to enquire into the problem through a succession of Commissions. Meantime the manufacturers experimented to discover methods of glazing their products without lead or with lead in the relatively harmless fritted state of low solubility lead glazes. The progress of the investigations and remedial measures are followed in detail leading to the final conquest of lead poisoning among dippers and their assistants.
\end{abstract}

Evidence is the life of Truth, and method the life of discourse; the former being requisite to convince the Understanding; the latter to facilitate the searches of it.

W. Charleton (1675)

Dr. Gavin Milroy's purpose in founding these annual lectures, inaugurated in 1888 , was to promote through succeeding lecturers the advancement of

*The Milroy Lecture delivered at the Royal College of Physicians, London, February 4, 1963. medical science towards the prevention of disease. He was, it appears from his writings, deeply disturbed "by the vast amount of protracted malaise and suffering, disablement, or lessened capacity for industrial work, and often too, of slow but eventually fatal sickness, in almost every region of the world, due to the multiform class of the cachexiae". These diseases, he observed, resulted in a depraved state of the whole or part of the body and were characterized by anaemia and asthenia. 
Plumbism or lead poisoning and potters' asthma or silicosis are two varieties of the cachexiae which have afflicted workers in the pottery industry of North Staffordshire, the Potteries, almost since its establishment there nearly 300 years ago. Generations of local surgeons and physicians, factory inspectors, Certifying Surgeons, practical potters and scientists have progressively added to the knowledge of the origin, prevalence, and social consequences of these maladies among the local population. Thereby they have assisted towards the control of lead poisoning and silicosis in the industry generally and their prevention in particular occupations and processes. The purpose of these lectures is to unfold the story of two conquests and thus salute the high endeavours and achievements of dedicated men and women.

\section{History of Lead Poisoning}

Few diseases known to medicine have been so widely studied and described as lead poisoning. During the 400 years between 1500 and 1900 it was endemic, often epidemic, in countries throughout the world. The starting point of precise knowledge of the disease may be fixed about 1572, the year in which according to Citois (Lat. Citesius, 1616), lead poisoning occurred as an epidemic in France in the province of Poitou. The characteristic symptom was severe persistent abdominal pain, so Citois named the disease colica Pictonum, that is the colic of the Pictones, the ancient Celtic tribe, who then inhabited Poitou. In time the term was applied generically to lead poisoning, otherwise saturnism or plumbism. The epidemic was due to drinking wine adulterated with litharge (lead oxide), which it was the custom of vintners to add to harsh sour wines to counteract their acidity and so improve their sweetness by the formation of sugar of lead (lead acetate). In 1675 an account of this practice was given by Dr. Walter Charleton, president of the College of Physicians from 1689 to 1692 , in a pamphlet entitled The Various Sicknesses of Wines and their Respective Remedies at this Day Commonly Used. Dr. Rice Charleton, who was elected physician to the Bath General Hospital in 1757, in An Inquiry into the Efficacy of Bath Waters in Palsies (1774) recorded an incident in which six persons simultaneously "became paralytic by drinking cyder brought to them at harvest work, in a new earthen pitcher, the inside of which was glazed." The effects were attributed to the solution of the lead in the glaze by the acid liquor. Devonshire colic (Huxham, 1752) attracted the attention of Dr. (later Sir George) Baker (1767), the distinguished president of the College of Physicians from 1785 to 1795 . He too observed similar accidental outbreaks of lead poisoning among harvest workers. From close clinical observation and wide knowledge Baker concluded that the Devonshire colic was similar to colica Pictonum in France, Hüttenkatze in Germany and Entrepado in Spain, all of which had been associated with adulteration of local wines.

Wedgwood, the celebrated Staffordshire potter, on July 21, 1773, in a letter to his partner Bentley mentioned that Dr. Percival of Manchester, then a recognized authority on lead poisoning, had, following a series of chemical experiments, recorded (Percival, 1788) that "vessels glazed with lead are improper for the preserving of acid fruits and pickles". Simultaneously Wedgwood learned that a Dr. Gouldson of Liverpool had published a pamphlet making the same assertions.

(I have frequently cited this reference without being able to trace the original. On this occasion the librarian at The Liverpool Medical Institution, unable to find it under Gouldson, noted that the year 1773 corresponded with the publication of an Essay on the Liverpool Spa Waters to which was added an appendix On the Accidental Use of Lead by Thomas Houlston, M.D.)

In this Houlston describes how the keeping of milk, buttermilk, sweetmeats, syrups, and even moist sugar in earthenware vessels glazed with lead induced symptoms of lead poisoning. Wedgwood's immediate reaction to these reports was "I will try to make a glaze without lead, and if I succeed will certainly advertise it". An allied source of accidental lead poisoning occurred in the preparation of medicaments by apothecaries. Lewis (quoted by Baker, 1785) remarked that "vinegar by a boiling heat may corrode so much of the vitrified lead as to receive from it noxious qualities". Furthermore, from the earliest times therapeutic virtues have been ascribed to saturnine medicines and external applications such as Goulard's lotion, but it did not escape notice that symptoms and signs of lead poisoning appeared as side effects. Indeed, it was through the administration of lead oxide in the treatment of cases of haematemesis and haemoptysis at St. Thomas's Hospital, London, between 1834 and 1840 that Burton (1839-1840) discovered the "blue line" on the gums, which diagnostic sign has since been associated with his name.

Contemporaneous with these accounts of lead poisoning due to fraudulent practices, accidental contamination and medical treatment, physicians reported the occurrence of the disease among workmen exposed in their employment to lead particles, effluvia, and emanations. In the mid-sixteenth century Agricola (1556) and Paracelsus (1567) described the disease in miners and smelters of lead 
ore. Stockhausen (1656) a century later extended the picture by his account of Hüttenkatze among lead miners and others at Goslar in Germany. Ramazzini (1705) was familiar with lead poisoning, a form of what he calls the metallic plagues among tradesmen. Chapter 5 of De Morbis Artificum Diatriba is devoted to the diseases of potters, De Figulorum Morbis. In this he describes how potters glazed their ware with calcined lead and so "received by mouth and nostrils and all the pores of the body, all the virulent parts of the lead ... and were thereupon seized with heavy disorders". During the eighteenth century the Charity Hospital in Paris became celebrated for its treatment of lead colic and so attracted a wide range of cases of diverse occurrence. It was a routine practice to enter the trade and employment of each patient in the hospital register. This enabled Gardane (1768, quoted by Baker, 1786) to analyse by occupation the cases for the years 1755 to 1767 . Painters, plumbers, and potters, it emerged, were the main tradesmen affected. Seventy years later Tanquerel des Planches made a special study of the disease at the same hospital. Between the years 1830 and 1838 he investigated 1,213 cases of lead colic. These provided the material for his classic treatise on the disease (Tanquerel des Planches, 1839). The cases included "54 manufacturers of earthern pottery and 7 manufacturers of china ware".

The clinical manifestations of the disease, acute and chronic, were widely known. These comprised colic, the "Dry Belly Ache" (Hunter, 1808), palsies and convulsions, which were associated with a wasting of the whole substance of the body and anaemia, that is cachexia. Descriptions of patients by early physicians are dominated by what is called the saturnine facies. Grisolle, in his inaugural thesis, Paris, 1844, wrote (I translate):

"The workmen (lead workers) are not long before they become pale and begin to grow thin. Their cheeks become sunken and the skin, particularly of the face, assumes a yellowish tinge, which is characteristic and in no wise resembles the yellow colour of jaundice. All the tissues lose colour, the blood is pale and diminished in amount."

\section{The Making of Pottery}

The making of pottery on the potter's wheel is one of the earliest domestic arts. In the Apocrypha (Ecclesiasticus, C. 38, 30), written in Greek between 200 and 300 B.C., we read:

"He (the potter) will fashion the clay with his arm, And will bend its strength in front of his feet;

He will apply his heart to finish the glazing;

And he will be wakeful to make clean the furnace."

$\chi \rho \hat{\imath} \sigma \mu \alpha$ (chrisma), here translated glazing, literally means to complete the smearing as with oil.
Plot (1686) in The Natural History of Staffordshire described the use of lead ores in the glazing of earthenware as carried out in that age:

"After the vessels are painted, they lead them with that sort of lead ore they call smithum, which is the smallest ore of all, beaten into dust, finely sifted and strewed upon them, which gives them the gloss."

Deposits of galena, lead sulphide, occurred locally. Following this dusting, the ware was fired in the oven. At a later period the glaze was prepared in liquid form and applied either by washing the pieces with the glaze or applying it with a brush. From these methods it was a natural development to dip the ware. At first this was done in the natural clay state but in 1750 Enoch Booth, a manufacturer of Tunstall, fired his ware and then dipped the "biscuit" in the fluid glaze. It appears that a little later in compounding glazes manufacturers began to use litharge, lead oxide, and white lead, lead carbonate. The deleterious effects of lead were observed among dippers and their assistants. Controversy arose as to the relative dangers of the different materials; the dippers considered that litharge was more hurtful than white lead. Josiah Wedgwood II, while admitting the hazards of dipping in lead glaze of either kind, called attention to the fact that some manufacturers added arsenic and so aggravated the pernicious effects.

Under the Health and Morals of Apprentices Act, 1802, Parliament for the first time sought to regulate the conditions of labour of children in cotton mills and factories. This legislation in due course led to an investigation of the "State of the Children Employed in the Manufactures of the United Kingdom". A Select Committee took evidence on this subject in pottery manufacture in 1816 . Josiah Wedgwood II, who gave evidence, was asked, "Do you think any part of your business is unwholesome?" He replied, "There is a part of the business which is unwholesome: it is that part of the business that is connected with the applying the glaze upon the surface of the ware called Dipping; . . . that glaze is composed in part of white lead, and like other businesses in which workmen have to do with lead, they are, if careless in their method of living, and dirty, very subject to disease."

Reference has already been made to the observations of Charleton, Baker, Percival, Houlston, and others in the solution of lead glazes by acids with consequent danger to consumers of various articles of food and drink stored in glazed earthen pots. Wedgwood's reaction was to prepare a glaze without lead. In 1822 the Royal Society of Arts awarded the large gold medal, the prize for that session, to $\mathrm{J}$. Meigh, Esq. of Shelton, Staffordshire, for a paper on "Glaze for vessels of common red earthenware not prejudicial to health of those who make use of them". 
The formula reveals that it was compounded with black manganese and contained no lead. Subsequent records of lead poisoning among dippers prove that Meigh's glaze was not generally adopted.

\section{Government Inquiries and Reports}

The first authoritative account of labour conditions in the pottery industry is contained in the Second Report of the Children's Employment Commission published in 1843. The Commissioners appointed Dr. Samuel Scriven to investigate and report on the Employment of Children and Young Persons in the District of the North Staffordshire Potteries and on the Actual State, Conditions and Treatment of Such Children and Young Persons. Dr. Scriven found abundant evidence of ill-health among dippers and their assistants. This is his description of work in the dipping house:-

\footnotetext{
"There are one or two adults with their attendant boys, whose business it is to bring the ware in its rough, or, in the phraseology of the potter, in its biscuit state, from the warehouse or painting room to the tub. By constant handling, the fingers become so smooth and delicate that they sometimes bleed, and thereby render the process of absorption more certain and rapid. The dipping itself, performed by the man, is momentary and when completed, the article is passed on to the boys for shelving and drying."
}

The Commissioners amplified this by explaining that "the fluid in which the article is dipped contains, among other ingredients, a considerable quantity of lead and in some cases arsenic". Scriven remarked that the dippers appeared dull and cadaverous and suffered from "paralysis, colica Pictonum, and a host of other nervous diseases, all in their exaggerated forms". Mr. J. B. Davies, surgeon, in his evidence expressed the opinion that glazes might be made free from white lead or other poisonous ingredients, while a fellow practitioner, Mr. Robert Garner, believed that the occurrence of lead poisoning could be diminished by better ventilation, cleanliness, and washing before meals. That the employers recognized the risks of working in the lead is reflected in the fact that boys employed as dippers' assistants were more highly paid than others "as an equivalent for the risk they run"; in modern parlance, danger money. In retrospect it is now possible to discern that the whole future struggle, extending over 100 years, against lead poisoning in potteries was foreshadowed in this report.

In the course of inquiries during 1860 into the excessive mortality from lung diseases in the Potteries districts of Stoke-on-Trent and Wolstanton, Greenhow (1861) recorded that dippers were exposed to the danger of lead poisoning, which, he observed, was manifested in them by "the characteristic blue line on the gums, by painters' colic and by paralysis".

Parliament appointed another Children's Employment Commission in 1862. The report (1863) disclosed that there were 180 earthenware and china factories in North Staffordshire, employing 30,000 operatives, of whom 6,500 were classified as young persons and 4,500 as children under 13 years of age. Mr. F. D. Longe, assistant commissioner, who made the investigations, largely confirmed the findings made by Scriven 20 years earlier. However, he was of the opinion that the glaze was less dangerous than formerly and concluded that "there is good reason to hope that even lead may be dispensed with, without rendering the glaze less efficient or more costly".

Following the Report of the Commission (1863) Parliament passed the Factory Acts Extension Act, 1864 , in which earthenware works were, for the first time, brought within factory legislation. As it will emerge that young persons were specially vulnerable to lead, it is noteworthy that in $\mathbf{1 8 6 4}$ the minimum age for employment of children in factories was 8 years and this was not raised to 10 until 1876. Provisions made under the Act of 1864 included periodical lime washing of premises, admission of fresh air, and limitation of the hours of labour of children, young persons, and women. The Act also introduced a class of special rules for "compelling the observance of the conditions necessary to insure the required degree of cleanliness and ventilation", and, what was probably most important of all, inspection by Factory Inspectors.

Thereafter there was no significant comment until 1875 when in the Supplement on Occupational Mortality in the Thirty-fifth Annual Report of the Registrar General, Farr recorded that: "The earthenware manufacture is one of the unhealthiest trades in the country." The causes were poison (lead) and dust (flint and clay).

Meantime the ravages of lead poisoning in the manufacture of white lead attracted public attention. The situation was grave and demanded prompt remedial measures. In 1878 children and young persons were excluded from this manufacture. Under the Factories (Prevention of Lead Poisoning) Act, 1883, standards were prescribed for ventilation, the provision of washing and lavatory accommodation and messrooms, and personal protection by special clothing and respirators. Gradually over the following years prevention was advanced through special rules. A new code of Special Rules for White Lead Works was introduced as from May 13, 1892. This rule is of particular interest:

"They (the occupiers of factories) shall arrange for a weekly visit by a doctor, who shall examine every worker 
individually and who shall enter the result of each examination in the proper register."

This legislation provided a prototype for dealing with other lead industries. All these developments had increasingly added to the responsibilities of the Inspector of Factories in the inspection and supervision of factory workers.

At the request of the Chief Inspector, Mr. Cramp, Superintending Inspector of Factories for North Staffordshire, in November, 1892, reviewed the current situation in the earthenware and china factories. He reported that where lead was used in glazing, lead poisoning was prevalent but local physicians had impressed on him that great improvement had taken place over the past 30 years, due, in their opinion, to the Factory Acts. Mr. Cramp noted that "some manufacturers used glazes without lead; others "fritted" it before use thereby rendering it (probably) insoluble".

\section{Terminology of Lead Glazes}

At this point it is necessary to digress to explain briefly the nomenclature of lead glazes. These are of two kinds, "raw" and "fritted" lead. Raw lead glaze is composed of silicious matter, i.e. flint, stone, clay, etc., borax combined with silica, etc., and lead either in the form of carbonate or oxide. To obtain a lead frit a certain portion of the silicious matter is melted, that is fused, with the lead. The resulting compound, which resembles glass, is a silicate of lead, the particular form depending on the proportions of lead and silicious matter fused together. The other ingredients, i.e. the rest of the silicious matter and the borax, are combined with silica to form a boro-silicate. The two frits, after pulverizing, are mixed together with a little added clay to form the final glaze mixture. The effect of melting the lead with silicious matter practically amounts to fixing it in such a manner that it is less liable to the action of acids, which it meets in passing through the human body, and largely reduces the likelihood of its absorption into the blood. If the frit is properly compounded to bi-silicate form, all but a small amount of the lead is rendered insoluble, and glazes so made are called "low solubility" glazes. The finished glaze generally contains from 12 to $22 \%$, sometimes more, of lead calculated as lead oxide, but after fritting with sufficient silicious materials only from 2 to $5 \%$ of the lead remains soluble in dilute hydrochloric acid $0.25 \%$, the equivalent of the acidity of gastric juices.

Leadless, it should be noted, is used in two distinct connotations. The first is the literal sense, without lead; the second is the legal sense in which "leadless" means "a glaze which does not contain more than one per cent of its dry weight of a lead compound calculated as lead monoxide" when tested in the prescribed manner.

To return to Cramp, he recommended that the manufacture of earthenware and china should statutorily be certified as "injurious to health". He drafted a suggested code of Special Rules, which, he believed, would raise all factories to the level of the best and interfere very little, if any, with what were model potteries. This marked the launching of the attack, which just over 50 years later in 1944, was to achieve the conquest of lead poisoning among dippers and associated workers.

\section{The Campaign against Lead}

On December 24, 1892, the Home Secretary certified the manufacture of earthenware as a dangerous trade within the meaning of section 8 of the Factory and Workshops Act, 1891. Meantime the Representative Committee of the Operative Potters and the Manufacturers had been examining the proposed Draft Rules. The operatives in their comments affirmed the dangers of lead poisoning and submitted that no raw lead should be used in any glaze for earthenware and china. The manufacturers rejected this and relied on fritted lead. Therefrom the opposing forces and the contentious matters emerged. The Home Secretary followed the established pattern by appointing a Committee "to enquire into the conditions under which the manufacture of pottery is carried on, with the object of diminishing any proved ill-effects on the health of the workpeople". Within three months the Committee presented their report (Report of Potteries Committee, 1893, H.M.S.O., London, C. 7240) and made recommendations including a code of Special Rules. These, amended to meet certain objections, became the Special Rules, 1894.

Inevitably questions almost immediately arose about the effectiveness of the Rules. Mr. J. H. Walmsley, H.M. Inspector of Factories for the Pottery District, reviewed (H.M. Chief Inspector of Factories Report for the year 1895, H.M.S.O., London, 1896, C. 8067) their operation for the first 12 months. In his preamble he rightly emphasized that the period under review was too short to produce any noticeable improvement in the health of workers. Local physicians, however, had advised him that new cases of plumbism were much less frequent than formerly and such cases as did occur were not so severe. The operatives, he commented, were antagonistic and unco-operative because they regarded the Rules as "a hardship forced upon them by the Factory department, to which the masters had been privy". The manufacturers, in turn, protested that 
the disease in nine cases out of 10 was due to the workmen's careless, dirty, slovenly habits and that "efficient washing of the hands with hot water and soap was the best preventative". There was one encouraging fact, namely, that practical trials of various fritted glazes were being advanced.

The right of Parliament to legislate for the regulation of dangerous trades had been established; concurrent discussions of the problems had revealed an increasing need for more and better statistics of sickness and deaths attributable to occupational diseases. On the recommendation of the Association of Certifying Surgeons and the Committee on Factory Statistics (H.M. Chief Inspector of Factories Report for the year 1895) lead poisoning was made compulsorily notifiable to the Chief Inspector of Factories by medical practitioners and manufacturers as from January 1, 1896. Meantime in the Supplement to the Fifty-fifth Annual Report of the Registrar General (1895) Dr. Tatham had embodied a mass of statistical information on the influence of occupations upon health. The analyses were based on the mortality returns of males for the three years 1890 to 1892 , calculated on the census figures for 1891. In dealing with deaths from lead poisoning, Tatham made this very significant observation:-

"The mortality directly (italics inserted) attributed to plumbism gives an imperfect measure of the injury resulting from the absorption of lead into the system."

He continues in reference to a table which he had made:

"It at once becomes evident that exposure to the risk of lead poisoning is associated with increased liability to disorders of the urinary and nervous systems. These figures leave us no room for doubt that the deaths which are definitely certified as due to plumbism constitute but a small proportion of the deaths really due to poisoning by lead among workers who are exposed to its influence."

With regard to plumbism among earthenware workers the mortality figures for disease of the nervous and urinary systems exceeded the standard for occupied males by 54 and $50 \%$ respectively. But Tatham himself, as critics quickly observed, did not avoid statistical pitfalls. For example the analysis was restricted to males only, age 15 and over, whereas it was known that deaths from lead poisoning had occurred in females and in young persons of 14 in the pottery industry.

During 1896, the first year of notification, 1,030 cases of lead poisoning were reported. Of these, 432 occurred in china and earthenware manufacture in the United Kingdom; North Staffordshire accounted for 351 cases among about 4,700 lead workers.
At the request of the Chief Inspector (Annual Report of the Chief Inspector of Factories for the year 1897; H.M.S.O., London) during 1897 Miss Paterson and Miss Deane, Inspectors of Factories, followed up 404 notified cases. These derived from 132 factories employing 3,040 persons in lead processes. The diagnosis was confirmed by the Certifying Surgeon in all but 23 cases. The inspectors reported many distressing cases including young persons, who, after comparatively short periods of employment in lead processes, died of convulsions. Men and women, they found, had been rendered blind, and the poison had pernicious effects on the blood-forming organs and, in women, on the reproductive functions.

In the compact Potteries population of 250,000 persons, 400 cases of lead poisoning annually among 5,000 employed in lead processes could not escape public notice, especially as these included many tragic cases involving paralysis, convulsions, and blindness. The noxious effects on women were particularly disturbing, namely, frequent miscarriage and still births, and even when babies were born alive many died soon after from fits. Other events focused attention on the problem. In $1898 \mathrm{Dr}$. Dowling Prendergast, senior physician at the North Staffordshire Infirmary, comprehensively reviewed the subject in a book entitled The Potter and Lead Poisoning. Another matter, which later was to have an important influence, was the first Workmen's Compensation Act, 1897, which came into effect on July 1, 1898. This Act covered accidents only.

$$
\text { Crisis-1898 }
$$

That lead poisoning affected workers in glazing processes in the manufacture of earthenware and china was not disputed, but the extent and seriousness of the problem engendered considerable controversy. Following compulsory notification of the disease in 1896, the subject had tended to become impersonal and increasingly an assessment and discussion of published figures. But in and around the Potteries there were many people who believed that the real facts were individuals, paralysed and blinded; most tragic of all were the afflicted women and their infants. In Hanley, the centre of the six Pottery towns (Figure) - Arnold Bennett considered that five was more euphonius-there existed at that time a body, The Women's Trade Union League, of which a Miss Gertrude Tuckwell was the very able and active secretary. On April 3, 1898, the League organized a meeting at the Hanley Labour Church, which resulted in the formation of the Reform Committee and marked the beginning of a popular agitation which was to be maintained for the next 15 years. 


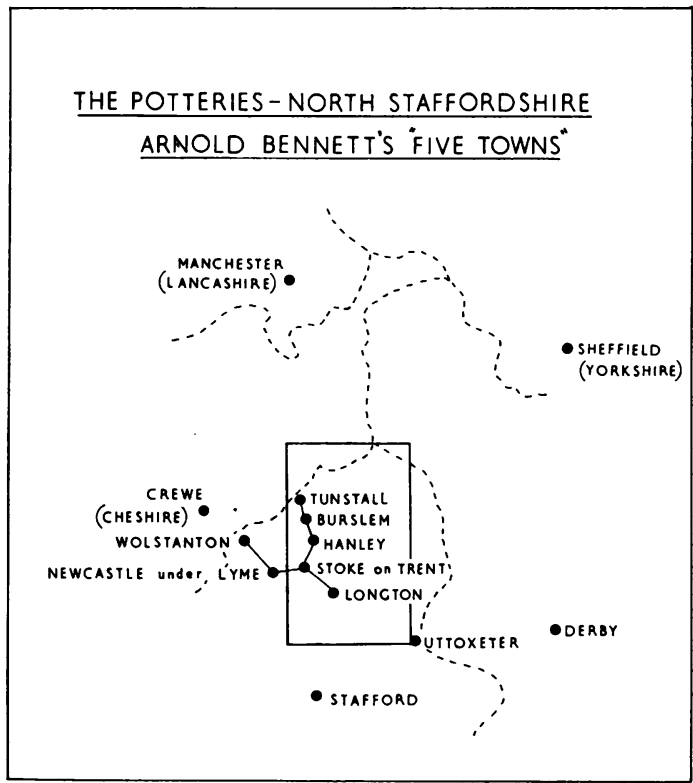

The object of the promoters was to direct attention to the evils of lead poisoning with a view to certain definite reforms. Among the points made at the inaugural meeting were that both employers and workers were blameworthy; that the mischief was not inevitable but was distinctly preventable; and that the paramount need was to attain the use of leadless glazes and meantime to restrict the employment of women and children in lead processes. The campaign, as events showed, was highly emotional in its approach and, it was alleged, was based on a few tragic cases. This notwithstanding, the League claimed to have a register of 100 acute cases and appealed for funds to enable the committee to assist these patients. To publicize the facts, to win supporters and funds, meetings were arranged throughout the country, and a vigorous campaign was maintained through national and local newspapers. Various devices were adopted to dramatize the situation. Thus patients were sent to hospitals as far apart as London and Newcastle-upon-Tyne, and Houses of Rest were established at Llanfairfechan, Matlock, and Wolverhampton. One effort which invoked criticism was a travelling exhibition of tiny cachectic babies which had been born to mothers suffering from the effects of lead. Relative to this, a special correspondent of The Times wrote (October 8 , 1898):-

"The influence of lead in causing abortion is wellknown to the women, who are in the habit of seconding the chances of poisoning at the factory by resorting to the chemist's shop."
A Hanley chemist had told him of purchases of diachylon (oxide of lead) in lumps of a pennyworth or two at a time.

Many notables, including the Duchess of Sutherland of Trentham Hall, Lord Hugh Cecil, Canon Gore, and Mrs. Asquith, actively supported the cause at public meetings and by arranging At Homes. The Duchess of Sutherland never failed to plead that people should follow her example and use only leadless glazed pottery. In support of this, exhibitions of such ware were arranged in connexion with meetings to demonstrate its high quality. On July 28,1898 , in answer to a question in the House, the Home Secretary announced that:-

“Her Majesty's Office of Works have issued a regulation that all articles for domestic use supplied under contract for the Public Department, the Houses of Parliament, and such of the Royal Palaces as are under their charge shall be made with leadless glaze."

This is an effective sanction still applied by the Government and Local Authorities in similar circumstances. In the House of Commons the campaign was ably led by Sir Charles Dilke, member for the Forest of Dean. He was supported by Mr. Burn, member for Battersea, whose sympathy derived from his experience of phosphorus poisoning in the manufacture of lucifer matches in the East End of London. Mr. Coghill, the local member of Parliament for Stoke-on-Trent, was pro-employer, and in the debate in the House he refuted the idea that the cases were largely due to lead poisoning stating that, in his opinion, they were really cases of arsenical poisoning from drinking contaminated beer.

In response to the public outcry the manufacturers claimed that they were 20 years in advance of public opinion and far ahead of the Government and scientists in their efforts to combat the disease. Some firms, it was asserted, had been fritting lead since 1850 and experiments and practical trials were constantly proceeding to discover satisfactory leadless glazes for all types of ware. They deplored the general indifference of the workers to the dangers of lead and argued that "their apathy was the greatest obstacle the reform committee had encountered".

That the Government were disturbed by the situation was soon proved by a rapid succession of measures. On May 7, 1898, little more than a month after the commencement of the public agitation, the Home Secretary invited Professor T. E. Thorpe, Principal of the Government Laboratory, and Professor Thomas Oliver, physician to The Royal Infirmary, Newcastle-upon-Tyne, to carry out an inquiry in accordance with the following terms of reference:- 
"It is admitted that in the manufacture of earthenware and china the workpeople incur grave danger of lead poisoning, owing to the use of glazes and pigments containing large proportions of lead; and the Secretary of State desires to ascertain:-

1. How far the danger may be diminished or removed by substituting for the carbonate of lead ordinarily used, either one or other less soluble compound of lead, e.g. (a) silicate, (b) "leadless" glaze.

2. How far any substitutes found to be harmless or less dangerous than the carbonate lend themselves to the varied practical requirements of the manufacture;

3. What other preventive measures can be adopted."

Almost immediately thereafter the Home Secretary received a deputation from the Potteries. Mr. Emery, president of the North Staffordshire Trades Council, asked that "the victims of lead poisoning should be included in the Workmen's Compensation Act, 1897'. He submitted that if this were done he believed that in six months' time lead poisoning would be a thing of the past. This, he asserted, had been the experience in Germany where the manufacturers had reacted quickly to save their pockets.

The regular announcement, often through questions in Parliament, of statistics of notified cases and fatalities became a constant source of harassment to the Home Secretary. The figures were criticized as inadequate, so creating a false impression of the facts. As always, one group argued that they exaggerated the problem, while others responded, with equal confidence, that they diminished it. The Chief Inspector of Factories, Dr. Arthur Whitelegge, realized the compelling need to ensure, so far as possible, the reliability of the statistics. Accordingly he addressed a circular letter to H.M. Coroners, emphasizing the importance of holding an inquest in all suspected fatal cases and of permitting the attendance of the Certifying Surgeon and a medical expert on behalf of the employers and workmen to be present at the post-mortem examination. Likewise all notified cases and the overall problem pointed to the need for expert official investigation and supervision. This was met on July 26, 1898, by the appointment of Dr. Thomas Morison Legge as first Medical Inspector of Factories. As subsequent events proved, this appointment was almost visionary for Legge's contribution to the control and prevention of lead poisoning proved not only national but international.

Concurrently it became apparent that the Special Rules of 1894 had fulfilled their purpose as a pilot measure and so they were amended in May, 1898, and for some manufacturers, who objected, in the following October. The main changes were the exclusion of persons under the age of 15 years from work in the dipping house or dippers' drying room and monthly examinations by the Certifying Surgeon of all women and young persons in named departments and processes. These examinations included power of suspension and prohibition of re-employment in any of the places or processes named. Increased importance was attached to exhaust ventilation thus: "In the process of ware cleaning after the dipper exhaust fans shall be used, or arrangements made for the dust to fall into water." Despite all these progressive measures Sir Charles Dilke accused the Home Secretary of "making experiment ground for delay".

In the interval Thorpe carried out extensive laboratory experiments and trials on glazes, and he and Oliver studied the practices of pottery manufacturers in other countries. On February 21, 1899, just nine months after appointment, their Reports on the Use of Lead in the Manufacture of Pottery were published. They accepted the evidence of the 1893 Committee that a serious incidence of lead poisoning existed in the manufacture of earthenware and china. Although acknowledging that some individual manufacturers had substituted fritted for raw lead and had experimented with leadless glazes, they concluded that no concerted action had been taken by the trade as a whole. They concluded:-

\footnotetext{
"We have no doubt whatsoever that leadless glazes of sufficient brilliancy, covering power and durability, and adapted to all kinds of table, domestic and sanitary ware,
} are now within the reach of manufacturers."

In extension of this they added:-

1. Many products can be glazed without lead;

2. Where lead cannot be dispensed with then fritted lead as a double silicate should be used.

The Report was duly referred to the manufacturers for comment. In a signed statement in reply they emphasized the commercial disaster which would overtake the earthenware and china industries if lead were prohibited. There was no dispute that certain common wares could be glazed without lead but the advantages of lead were the high quality, competitive goods which it produced and the wide margin of error it permitted during production, thereby reducing to a minimum the quantity of spoiled ware. The manufacturers, however, agreed to abandon the use of raw lead and to frit all lead in glazes, but they protested altogether against any reduction of the total permitted lead content. Thereupon in August, 1900 , the Secretary of State issued draft amended Special Rules giving effect and adhering to the findings of Thorpe and Oliver. The draft, when sent to the manufacturers, was accompanied by an explanatory letter in which the main facts were reviewed. In this the Home Secretary stressed that the use of 
fritted glazes, which he proposed, could not be based on the amount of lead in the fritt, but on the solubility of the lead. He further commented that the Rules represented good practice developed and already followed by leading manufacturers. With reference to lead the principal alterations were comprised in the following Rules (summarized):-

1. All lead for use in specified processes to be fritted;

2. Lead to be in insoluble form to such a degree that when tested in the prescribed method it did not yield more than $2 \%$ of its dry weight of a soluble lead compound calculated as lead monoxide; . . .

4. No woman, young person or child to be employed in the preparation or manufacture of fritts, glazes or colours; ...

6. Monthly examinations of lead workers extended to all persons; power of suspension by Certifying Surgeon.

The manufacturers supported the Rules generally. They objected in toto to the $2 \%$ limit of solubility but were agreeable to accepting a standard not exceeding $5 \%$. In accordance with the Factory and Workshops Acts of 1891 and 1895 they insisted on arbitration on the disputed matters. The operatives on their side signified opposition to the monthly examinations so long as lead poisoning was not covered by the Workmen's Compensation Act. The employers also resisted suspension on the grounds that it would deprive them of skilled labour, while suspended men would have difficulty in obtaining alternative suitable employment without loss of wages.

Arbitration proceedings, with Lord James of Hereford as umpire, commenced at Stoke-on-Trent on November 7,1901 . In the preliminary statements it was emphasized that both the Home Office and the employers were anxious to mitigate and, if possible, abolish the evil of lead poisoning in the industry. On behalf of the Home Office Miss Anderson, Inspector of Factories, presented evidence on the current prevalence and manifestations of the disease in the various occupations. The employers criticized the statistics, which they asserted were the source of mischievous representation and exaggeration, as shown by the sentimental outcries of philanthropic persons. The critical issue was the standard of solubility of lead fixed at $2 \%$. The Home Office relied on the testimony of Professor Thorpe. Experts on behalf of the manufacturers argued that Thorpe's experiments, no matter how successful in laboratory trials, did not prove that they could be applied on a manufacturing scale. The need, it was underlined, was to make practical trials with various fritts in the factories under ordinary conditions of bulk production. The employers asserted that the method of glazing must be practicable, reliable under a wide variety of conditions, and produce durable quality goods at prices competitive against foreign manufacturers. Finally they believe the Special Rules of 1894 and 1898 had greatly diminished the cases in number and severity and so "there was no need for further interference". On the fifth day of the proceedings, before many of the witnesses had been called, Lord James, after consultation with Counsel, suddenly terminated the hearing and adjourned consideration of the disputed Rules for 18 months and thereafter if necessary. This abrupt ending was widely interpreted as a public rebuff to the Home Office for initiating precipitate legislation in advance of what was warranted by the current state of knowledge. The Evening Standard spoke of the Humiliation of the Home Office; The Times and Manchester Guardian supported the employers, but The Lancet deplored the turn of events, commenting "We view the decision with the deepest dismay; it is premature and dangerous".

In his closing address, Lord James made several very cogent comments, for example:

"The interests of employers may be personal, profit may be theirs-but at the same time interference with trade, which is a trade of the country, and which affects our community as a whole, should not take place if it can be avoided."

\section{And again:}

"It is not only the duty of the State to protect workmen against damage to health and life but also it is not less a duty to see that industries are not crippled or endangered by excessive restriction."

As to the difficulties of small firms in complying for financial and other reasons he was unequivocal in his statement that "they will have to overcome the difficulties, they employ human beings". But the employers did not go scot-free for it was agreed that manufacturers who continued to use lead in any form would enter into a voluntary scheme of mutual insurance to provide compensation for the disease. This was the genesis of workmen's compensation for industrial diseases as opposed to accidents in Great Britain; it was already in operation in Germany.

The adjournment signalled an upsurge in the spate of lectures, exhibitions, newspaper articles, and correspondence, all propaganda for the various viewpoints. Miss Tuckwell and her committee did not abate their emotional appeals nor their incitement to boycott all lead glazed pottery.

The arbitration under Lord James was resumed in June, 1903, and completed expeditiously. The umpire's final award included compulsory compensation for lead poisoning contracted in work in potteries; extension of the monthly medical examina- 
tions to adult male lead workers and, most significant of all, the adoption of $5 \%$ as the level of lead solubility. The award was immediately translated into the Special Rules of 1903 with effect from February 1, 1904. Then on July 1, 1907, the Workmen's Compensation Act, 1906, came into force providing for the payment of compensation to all persons (and their dependants) who contracted lead poisoning arising out of and in the course of their employment. This was the last legislation change, especially affecting potteries, prior to the appointment of the Hatch Committee in May, 1908. It is of interest to remark in passing that almost the final shot in the popular campaign was fired by Mr. George Bernard Shaw at Caxton Hall, Westminster, on June 29, 1906, in a lecture entitled "Poisoning the Proletariat". Shaw urged that remedy of the evil could only be achieved through effective legislation and concluded, "Those who live in the guilty society, cannot help being guilty themselves". The lecture was supported by an exhibition of leadless glazed ware.

Progressive advance against industrial disease, if it is to be maintained, demands constant vigilance and regular appraisal of results, and this, as has emerged, was a noteworthy feature of the Government's attack on lead poisoning in potteries. On May 12, 1908, the Home Secretary appointed yet another Departmental Committee on Lead etc. . . . in Potteries under the chairmanship of Ernest F. G. Hatch, Esq. The membership of the Committee reflected what might be regarded as gamesmanship on the part of the Home Secretary in that it included Mr. William Burton, a manufacturer and the leading protagonist of the manufacturers, and Miss Tuckwell, the champion of the women and children in the public agitation.

The Committee were invited "To consider the dangers attendant to the use of lead in the various branches of the manufacture of china and earthenware and in the processes incidental thereto, including the making of transfers, and to report how far these can be obviated or lessened:-

By improving appliances and methods; or

By conducting any of these processes in separate rooms; or

By limitation of the use of lead; or

By substitution of harmless lead compounds for raw lead; or

By substitution of other materials for lead; or

By controlling the employment of susceptible persons in lead processes; or

By precautions for detection of lead poisoning in the earlier stages, or otherwise, and how far such precautionary measures are reasonably practicable generally with regard to the several branches of the said manufacture".
These terms of reference, it will be observed, were comprehensive and admirably framed to reflect current accumulated knowledge and experience, practical, scientific, and medical.

The Report was presented to the Home Secretary in June, 1910. In the course of their deliberations extending over two years, the Committee heard considerable evidence, most of it a repetition of that given to previous Committees but brought up to date. The members also visited 26 potteries representative of the various branches of manufacture. It emerged that the industry had been steadily expanding so that in 1907 it comprised 550 factories, employing 63,000 workers of whom only 6,865 were engaged in processes involving contact with lead. Cases of lead poisoning, many fatal, were very prevalent. In the five years 1904 to 1908 in pottery manufacture throughout Great Britain 517 cases were confirmed by Certifying Surgeons. The cases were very unevenly distributed as shown by the analysis that five potteries contributed 75 cases, 17 contributed 119, and 151 contributed 323; the remaining 377 factories contributed none. Despite the heavy costs of insuring against compensation and the fees for monthly examinations the Committee found that of 481 factories no less than $377(78 \%)$ preferred to incur the expense rather than give up the privilege of using lead in the glaze without restriction to $5 \%$ solubility level. Professor Thorpe (now Sir Edward), who again gave evidence, adhered to his opinions and conclusions reported in 1899. As to the clinical aspects, Dr. Legge gave evidence on an investigation of 497 cases occurring between 1903 and 1907. Of these, 217 were males and of these 42 cases $(19.3 \%)$ were classified as severe; 280 were females of whom $35(12.5 \%)$ were severe. "Severe" cases were defined as those showing (1) marked paralysis, such as total wrist drop; and (2) encephalopathic conditions, such as convulsions; optic neuritis, that is, loss of sight, temporary or complete; and mental affections. Dr. G. Reid, Medical Officer of Health for Stoke-on-Trent and a member of the Committee, made special enquiries into the specific effects of lead on women. He confirmed that there was a significant excess of miscarriages among female lead workers as compared with artisan mothers not exposed to lead. In this matter it is of interest that some local medical practitioners (Shufflebotham, 1901) were of opinion that this excess occurred where the father was a lead worker and the mother had never been employed in lead processes.

The Committee in their Report recognized that the danger to the workers of handling lead was real and could cause poisoning or general deterioration in health. While acknowledging that leadless and low 
solubility glazes might be unsuitable for certain classes of ware, there were many types for which, in their opinion, they were satisfactory. They recommended increased regulation of the employment of women and young persons, and a shorter working week which in the case of dippers should not exceed 48 hours. They also advised the supply of milk or milk cocoa at the employer's expense. Furthermore they emphasized the necessity of minimizing the danger and suggested that every inducement and encouragement should be given to manufacturers both to persevere with their experiments in search of satisfactory leadless and low solubility glazes, and to introduce them whenever possible. Miss Tuckwell, although supporting the precautions recommended by the other members, dissented and did not sign the Report. In a supplementary memorandum she cited figures showing that the disease was considerably more serious in prevalence and noxious effects among women than in men. She adhered adamantly to her public campaign for leadless glazes. Finally the Committee proposed a code of Regulations (note not Rules) embodying their recomméndations. The broad distinction between Rules and Regulations is that the former are mainly concerned in outlining general principles by which the health of operatives might be safeguarded. Regulations, on the other hand, prescribe in detail specific measures governing manufacturing processes, environmental conditions, and general conditions of labour.

After the usual deliberations between all parties concerned the recommendations of the Hatch Committee led to the enactment of the Regulations for the Manufacture and Decoration of Pottery dated January 2, 1913. The Regulations restricted the employment of women and young persons and children in various lead processes and occupations. The initial and periodical medical examinations (involving permanent suspension) at monthly intervals were applied to all persons in prescribed processes. The examinations were to be made by the "Surgeon" who was defined not as the Certifying Surgeon but as the Certifying Factory Surgeon. The sections on protective clothing, proper storage facilities for outdoor garments, and the eating of food in messrooms were merely a development of those in previous Rules. The following provision was new:

\footnotetext{
"A supply of milk or cocoa made with milk, shall be provided for all women and young persons in scheduled processes who commence work before 9 a.m. Not less than half a pint shall be provided for each such worker at the expense of the occupier."
}

The provisions for suppression of dust in lead pro- cesses were considerably extended, reflecting Legge's evidence and creed which he later enunciated in the axiom (Legge, 1934):

"Practically all industrial lead poisoning is due to the inhalation of dust and fumes; and if you stop their inhalation you will stop the poisoning."

In a book (Burton, 1913) compiled for the guidance of manufacturers on the new Regulations, William Burton, a member of the Hatch Committee, referred to "the revolution that had taken place in medical opinion during the last ten years as to the exact way in which pottery workers were liable to absorb lead compounds into their system; originally skin absorption, then ingestion and now absorption through the lungs". I wonder how three centuries of classic writers on lead poisoning, including Citois, Paracelsus, Ramazzini, Baker, Gardane, and Tanquerel, would have learned of these progressive discoveries.

The Pottery Regulations, 1913, duly came into force but the 1914-1918 war and the consequent disorganization of the industry prevented close scrutiny of their operation. It was not until 1940 that they became the subject of a Special Report by the Chief Inspector of Factories. In that year there were only four cases of lead poisoning. The Chief Inspector commented that "this happy position had only been achieved by unremitting vigilance and could only be maintained by meticulous observation of the Regulations". This task had been assumed and maintained by the National Council of the Pottery Industry, the first Joint Industrial Council, which was established in Stoke-on-Trent in January, 1918. The Council comprised equal representation of the employers' and operatives' organizations, who were assisted in the various committees by co-opted experts. As an index of the trend of the use of lead in glazes, it appears that during 1940151 samples of glaze were taken by the Inspector of Factories and in six only was the lead content in excess of $5 \%$.

In a story of this kind it has often been tempting to quote pages of figures and tables. The evidence of the Committees of Inquiry and the Annual Reports of the Chief Inspector of Factories and Workshops are crammed full of such data. But, as is still the case, the statistics, including those officially prepared, are often incomplete and not uniformly presented from year to year. In this way they invite queries and criticism and can be adapted to support any case either directly or by default. Ultimately, however, the broad trend emerges. Whatever the variation over the previous 100 years, the undisputed fact is that in 1944 there was not a single case of lead poisoning reported to the Chief Inspector in or in 
connexion with glazing processes in china and earthenware manufacture in North Staffordshire. The gradual advance through Inquiries, Special Rules and Regulations had achieved the objective.

$$
\text { Victory-1947 }
$$

The Pottery (Health) Special Regulations, 1947, signalled the success and assured that there would be no retreat. As from October 7, 1948 (1949 in the case of tiles) it was enacted that "no glaze which is not a leadless glaze or a low solubility glaze shall be used in a factory to which these Regulations apply in the manufacture of pottery and glazed tiles". Low solubility was defined at the $5 \%$ level. The wider aspects of prevention were consolidated in the Pottery (Health and Welfare) Special Regulations, 1950.

Not a single case of lead poisoning in glazing processes in potteries was recorded by H.M. Chief Inspector of Factories in 1944, and since then there have only been four cases (Table). Some recent studies by the Medical Inspectorate of Factories, using blood examinations, among glost placers showed no evidence of any lead absorption in these workers (Biden-Steele, personal communication).

The story is ended and in conclusion I submit for your meditation these words of Francis Bacon (1605):

"It is the true office of history to represent the events, together with the counsels, and to leave the

TABLE

NOTIFIED CASES OF LEAD POISONING IN CHINA AND EARTHENWARE MANUFACTURE IN NORTH STAFFORDSHIRE 1899-1961

\begin{tabular}{c|c|c}
\hline \multirow{2}{*}{ Quinquennia } & Col. 1 & Col. 2 \\
\cline { 2 - 3 } & Total Cases & $\begin{array}{c}\text { Fatal Cases } \\
\text { (included in Col. 1) }\end{array}$ \\
\hline $1899-1903$ & 573 & 22 \\
$1904-1908$ & 445 & 28 \\
$1909-1913$ & 325 & 42 \\
$1914-1918$ & 91 & 20 \\
$1919-1923$ & 177 & 49 \\
$1924-1928$ & 166 & 32 \\
$1929-1933$ & 74 & 26 \\
$1934-1938$ & 86 & 5 \\
$1939-1943$ & 17 & 1 \\
$1944-1948$ & 1 & 1 \\
$1949-1953$ & 3 & 0 \\
$1954-1958$ & 0 & 0 \\
$1959-1963$ & 0 & \\
\hline
\end{tabular}

Source: H.M. Inspector of Factories, Stoke-on-Trent observations and conclusions therefrom to the liberty and faculty of every man's judgment."

(Proficience and Advancement of Learning, Book 1).

\section{REFERENCES}

Agricola, G. (1556). De Re Metallica. Basel.

Baker, G. (1767). An Essay Concerning the Cause of the Endemical Colic of Devonshire. London.

(1785). Medical Transactions of College of Physicians, 3, 427.

(1786). Medical Transactions of College of Physicians. 2, (2nd ed.), 443.

Burton, H. (1839-1840). Lancet, 1, 485, 661.

Burton, W. (1913). An Analysis of the Regulations Governing the Manufacture of Pottery in the British Isles. Manchester.

Charleton, R. (1774). An Inquiry into the Efficacy of Bath Waters in Palsies. Second tract in Three Tracts on Bath Water. Bath.

Charleton, W. (1675). The Mysterie of Vintners of a Brief Discourse concerning The Various Sicknesses of Wines and Their concerning The Various Sicknesses of Wines and Their
Respective Remedies, at This Day Commonly Used. London.

Citois, Francois (1616). De Novo et Populari apud Pictones Dolore Colioco Biolioso Diatriba. British Museum 11676 22(2).

Gardane (1768). See Baker, G. (1786).

Greenhow, E. H. (1861). See Third Report of the Medical Officer of the Privy Council, 1860, London, 1861.

Grisolle, A. (1844). Traité Elémentaire et Pratique de Pathologie Interne.

Houlston, T. (1773). Essays on the Liverpool Spa Water. Liverpool. Hunter, J. (1808). Observations on the Diseases of the Army in Jamaica, 3 rd ed. London.

Huxham, J. (1752). Opusculum De Morbo Colico Damnoniensi. London. (Available Glasgow University Library G16-L1).

Legge, T. M. (1934). Industrial Maladies. London.

Meiklejohn, A. (1954). Brit. J. industr. Med. 11, 40.
Paracelsus, T. (1567). Von der Bergsucht. Dilingen.

Percival, T. (1788). Essays Medical, Philosophical and Experimental. Warrington.

Plot, R. (1686). The Natural History of Staffordshire. Oxford.

Prendergast, W. D. (1898). The Potter and Lead Poisoning. London.

Prendergast, W. D. (1898). The Potter and Lead Poisoning. London. English) London.

Shufflebotham, F. (1901). Lancet, 2, 1109.

Stockhausen, S. (1656). Libellus de Lythargyrii fumo noxio mortifico ejusque metallico frequentiori Hütten Katze oder Hütten Rauch vulgo dicto. Goslar.

Tanquerel des Planches (1839). Traité des Maladies de Plomb ou Saturnines. Paris.

\section{Reports}

Children's Employment Commission (1843). Second Report of the Commissioners Trades and Manufactures. London, H.M.S.O.

Third Report of the Medical Officer of the Privy Council (1860). London, 1861.

Children's Employment Commission (1862). First Report of the Commissioners with Appendix. London, H.M.S.O., 1863.

Manufacture of China and Earthenware (1893). Report on The Conditions of Labour in Potteries, The Injurious Effects Upon the Health of the Workpeople, and the Proposed Remedies. London, H.M.S.O.

Thorpe, T. E. and Oliver, T. (1899). Report on the Employment of Compounds of Lead in the Manufacture of Pottery. London, H.M.S.O.

Report of the Departmental Committee on Lead, Dust and Other Causes in the Manufacture of Earthenware and China with Appendices and Minutes of Evidence. (1910). London, H.M.S.O. Cd. 5219, 5278 and 5385 .

Annual Reports of H.M. Chief Inspector of Factories and Workshops. (1892 continued). London, H.M.S.O.

Special Report of the Chief Inspector of Factories in the Regulations for the Pottery Industry for the year 1940 (1941). London, H.M.S.O.

Farr, W. (1875). Supplement to the Thirty-fifth Annual Report of the Registrar General. London, H.M.S.O. (C.-1155-I) 